\title{
Jaminan Kemurnian Al-Qur'an \\ Surah al-Isra' Ayat 88, Hud Ayat 13, Yunus Ayat 38 dan al- \\ Baqarah Ayat 23 Persepektif Abu Hayyan al-Andalusi dalam kitab Al-Bahr al-Muhith \\ Kajian Tafsir Tematik
}

\section{H. Taufiqurrohman \\ IAI Al-Khairat Pamekasan \\ taufiqurrohman@alkhairat.ac.id}

\begin{abstract}
Abstrak: Allah menurunkan kitab suci Al qur'an dan sampai saat ini masih terjaga kemurniannya. Tentu banyak kaum kafir untuk merusak kemurnian Al Qur'an tersebut. Namun dalam hal ini sekalipun mereka gotong royong mengajak semua manusia, lakiperempuan, kafir atau mukmin, yang memiliki keraguan pada alQur'an, mereka dapat dipastikan tidak akan bisa mendatangkan dan meniru al-Qur'an. Dalam hal ini penulis tertarik untuk mengkaji apa saja jaminan kemurnian Al qur'an di berbagai surah menurut persepektif Abu hayyan al- Andalusi dalam kitab Al-Bahr al-Muhith. Kajian ini menggunakan kajian Tafsir tematik. Setelah dilakukan kajian, penulis menemukan hal hal terkait macam-macam tantangan yang diberikan al-Qur'an ada empat tingkatan. Ini juga dikatakan sebagai tinggkatan mukjizad al-Qur'an. Itu pula merupakan jaminan atas kemurnia al-Qur'an.
\end{abstract}

Kata kunci: Kemurnian Al Qur'an,

\section{Prolog}

Al-Qur'an adalah satu-satunya kitab wahyu yang masih terjaga kemurniannya. Walaupun banyak sekali orang-orang yang ingin merubah isinya, tadak satupun dari mereka berhasil melakukan perubahan teks suci yang sudah dijamin itu. Allah dengan tegas mengatakan dalam surah al-Hijr "Sesungguhnya Kamilah yang menurunkan Al Quran, dan sesungguhnya Kami benar-benar memeliharanya." "1

Sejak awal al-Qur'an diturunkan sampai saat ini, tiada hentihentinya masih saja banyak ditemukan di berbagai belahan dunia orang-orang yang berkeinginan untuk merubah al-Qur'an dari bentuk

\footnotetext{
${ }^{1}$ Depertemen Agama RI, Al-Qur'an dan terjamah (Bandung, Al-Jumanatul Ali, 2005),
} 
aslinya, atau berkeinginan untuk menandingi kehebatan isinya. Hanya saja usaha mereka sia-sia begitu saja, tak sedikitpun al-Qur'an dapat terpengaruhi dengan niat licik mereka. ${ }^{2}$ Bahkan penghinaan yang mereka lakukan untuk menista, merubah dan melecehkan teks suci itu, terbalik arah, tidak sedikit dari mereka yang mendapatkan teror dan kecaman keras, bahkan meninggal dalam kondisi yang sangat mengenaskan. Seperti yang telah dikabarkan oleh media-media sosial

Jika dilihat dari segi redaksinya, al-Qur'an adalah sebuah teks yang memilki keistimiwaan luar biasa, melebihi keistimewaan hasil karya-karya para sastrawan dunia. Sampai detik ini belum pernah ditemukan sebuah karya yang memiliki kehebatan melebihi kehebatan al-Qur'an. Maka tidak berlebihan jika dikatakan, Bahwa redaksi bahasa al-Qur'an tidak dapat ditandingi dengan redaksi bahasa apapun. Karya-karya manusia yang mendunia tidak mampu bersaing dengan keindahan kesusastraannya, al-Qur'an adalah satu-satunya kitab yang dapat mewakili dan menampung semua disiplin keilmua. Al-Qur'an juga sebagai satu-satunya kitab yang mempu merekam semua jejak perjalanan orang-orang terdahulu. Al-Quran juga sebagai wahyu terahir yang mampu memberikan informasi kehidupan dunia dan kehidupan akhirat

Ada 4 ayat yang secara tegas memberikan pernyataan, bahwa tidak akan pernah ada manusia yang dapat menandingi keagungan alQuran sampai kanpanpun. empat ayat itu memberikan jaminan tegas bahwa al-Qur'an akan tetap menjadi kitab suci dan akan tetap terjamin kemurniannya.

Ayat-ayat yang menjamin kemurnian al-Qur'an adalah; sura al-Isra' ayat 88 , Hud ayat 13 , Yunus ayat 38 dan al-Baqarah ayat 23 .

\section{Klasifikasi Ayat-Ayat Al-Qur'an Berdasarkan Sebab Nuzul}

1. Surah al-Isra' ayat 88. Allah berfirman.

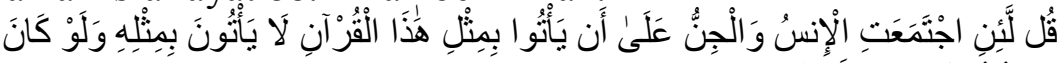

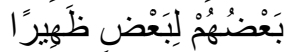

"Katakanlah: "Sesungguhnya jika manusia dan jin berkumpul untuk membuat yang serupa Al Quran ini, niscaya mereka tidak akan dapat membuat yang serupa dengan Dia, Sekalipun sebagian mereka menjadi pembantu bagi sebagian yang lain".

\footnotetext{
${ }^{2}$ Muhammad Muhammad Daud, Kamal Lughah al-Qur'an Bain Haqaiq al-I'ja wa Awham al-Khushum ( Kairo: Dar al-Mannar, 2007), 189.

${ }^{3}$ Depertemen agama RI, Al-Qur'an dan terjamah (Bandung, Al-Jumanatul Ali, 2005), 292.
} 
a. Sebab nuzul al-Isra' ayat: 88

1) Dikeluarkan oleh Ibn Ishaq dan Ibn Jarir melalui Said atau Ikrimah dari Ibn Abbas, beliau berkata: telah datang kepada Nabi Muhammad Saw. Salam bin Masykam, bersama rombongan kaum Yahudi, mereka berkata kepada Nabi: bagaimana saya bisa ikut kepada engkau (Muhammad) sedangkan engkau meninggalkan kiblat kami, dan sesungguhnya yang engkau bawa ini (alQur'an), kami menilai tidak ada kecocokaan, tidak seperti Taurat? Turunkanlah sebuah kitab bagi kami yang kami dapat mengenalnya, kalu tidak, kami akan datang lagi kepada-mu dengan membawa kitab lain seperti yang engkau bawa, kemudian Allah menurunkan ayat 88 surah al-Isra' sebagai jawaban bagi mereka yang menentangnya ${ }^{4}$

2) Diriwayatkan, sesungguhnya kelompok orang Quraisy, mereka berkata kepada Rasululah Saw. Datangkanlah sebuah ayat yang gharib kepada kami selain al-Qur'an ini, maka sungguh kami mampu mendatangkan seperti alQur'an ini, maka turunlah ayat 88 surah al-Isra' sebagai jawaban bagi mereka ${ }^{5}$

b. Munasabah al-Isra' ayat: 88

1) Munasabah ayat 88 dengan ayat sebelumnya:

Jika surah al-Isra' ayat 88 dikaitkan dengan ayat sebelumnya bahwa, jika Allah menghendaki melenyapkan apa yang telah Allah wahyukan kepada Nabi Muhamad, maka dengan pelenyapan itu Nabi Muhammad tidak akan mendapatkan seorang pembelapun terhadap Allah, kecuali karena rahmat-Nya. Oleh karenanya, setelah wahyu (alQur'an) lenyap dari hafalan para hafiz, lenyap dalam tulisan mushaf, maka tidak seorangpun mampu mewujudkan kembali seperti sedia kala, walaupun manusia dan Jin bersatu untuk membuatnya. Akan tetapi rahmat Allah membiarkan al-Qur'an utuh (tidak lenyap) sampai ahir zaman. Ini merupakan pemberian rahmat dan

\footnotetext{
${ }^{4}$ Jalaluddin Abdurrahman as-Suyuthi, Lubab an-Nuqul fi Asbab al-Nuzul (Kairo: Dar Al-Haitsam, 2005), 127-128.

${ }^{5}$ Muhammad Yususf Abu Hayyan al-Andalusi, Al-Bahr al-Muhith ( Bairut: Dar AlFikr, 1992), juz 7, 109.
} 
nikmat dari Allah atas ketetapan al-Qur'an dijaga dalam hafalan dan dijaga dalam keutuhannya. ${ }^{6}$

Abu Hayyan mengatakan di dalam kitab Bahr Muhith: setelah Allah memberikan pangkat kenabiyan kepada Nabi Muhammad Saw, dengan dibekali wahyu berupa al-Qur'an, adalah merupakan nikmat terbesar yang diberikan kepada Nabi Muhammad, sehingga keberadaannya terjamin sampai akhir masa. Tidak seorangpun dapat menandingi kehebatannya, walaupun semua bersatu saling tolong-menolong untuk menyainginya, mereka akan tetap lemah dihadapan alQur'an. Sehebat apapun mereka, sekalupun jin seperti yang telah terjadi pada masa Nabi Sulaiman. Bahkan para malaikat (misalny), mereka semua tidak akan bisa mendatangkan berupa tulisan semisal al-Qur'an ${ }^{7}$

Pernyataan ini ditegaskan Allah dalm surah al-Isra' pada ayat 86-87, yaitu ayat sebelum 88 . Allah berfirman:

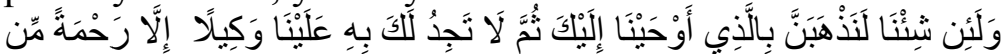

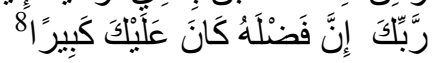

2) Munasabah ayat 88 dengan ayat setelahnya:

Munasabah ayat 88 surah al-Isra' dengan ayat 89 memberikan penegasan, bahwa, kebanyakan manusia tidak menyukai kepada al-Qur'an, walaupun telah diulang-ulang kepada mereka berbagai macam perumpamaan. Banyaknya contoh yang di sampaikan dalam al-Qur'an, mulai dari kehidupan orang-orang terdahulu, tidak bertambah percaya, melainkan mengingkari pada wahyu yang dibawa nabinya.

Lebih parah lagi mereka meminta kepada Rasulullah Saw. Tidak hanya urusan wahyu (al-Qur'an) atau akhirat. Tetapi untuk percaya kepada Rasulullah Saw. Mereka meminta agar Rasulullah memancarkan mata air dari bumi, menjatuhkan langit berkeping-keping, mendatangkan Allah dan malaikat berhadap-hadapan

\footnotetext{
${ }^{6}$ Abi al-Qasim Jar Allah Muhammad bin 'Uar al-Zamakhshari, al-Kashshaf 'An Haqaiq al-Tanzil wa 'Uyun al-Aqawil fi Wujuh al-Ta'wil (Bairut: Dar al-Fikr,2006), juz 6, 464-465.

${ }^{7}$ Muhammad Yususf Abu Hayyan al-Andalusi, Al-Bahr al-Muhith ( Bairut: Dar AlFikr, 1992), juz 7, 108.

${ }^{8}$ QS. Al-Isra'/17: 86-87
} 
dengan mereka, membuat rumah dari emas, bahkan sampai-sampai engkau (Muhammad) naik ke langit, sekali-kali kami tidak akan pernah percara kenaikan-mu, hingga kamu turunkan kepada kami sebuah kitab yang kami baca.

Sungguh luar biasa penulakan yang mereka lontarkan kepada Nabi Muhammad. Bahasa itu mereka katakan pada saat mereka tidak menerima al-Qur'an sebagai kitab suci dan tidak percaya kepada al-Qur'an sebagai wahyu. Perkataan mereka ditegaskan pada ayat 89-93 surah al-Isra'. Teks ayatnya berbunyi:

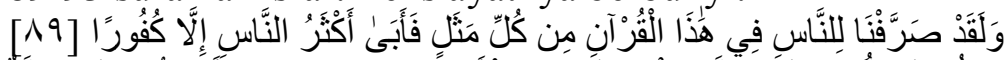

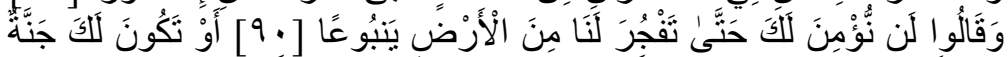

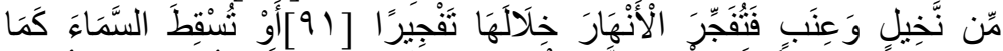

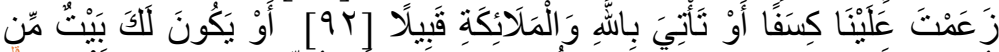

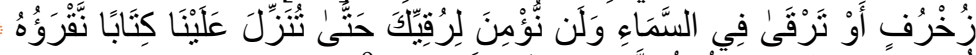

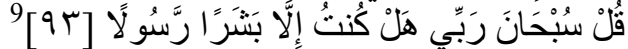

c. Analisis teks ayat 88 surah al-Isra'

1) Lafadz الإنس و الجن Lear Le

Secara khusus Allah menyebutkan dua kelompon ini, karena yang biasa ingkar kepada al-Qur'an yaitu dari golongan manusia dan jin. Tidak dengan malaikat yang selalu ta'at kepada Allah. Tantangan ayat itu ditujukan kepada manusia dan jin, karena Nabi Muhammad diutus kepada kelompok itu untuk membawa kejalan yang mustaqim $^{10}$

2) Lafadz بمثل

بمثل Pada ayat 88 surah al-Isra', terdapat lafadz yang diulang dua kali. Pertama artinya adalah al-Qur'an. Kedua, mitsli artinya adalah hasil karya selain al-Qur'an. Ia memiliki pengertian; bahwa yang dimaksudkan adalah karya yang dituliskan memiliki kesamaan sepenuhnya dengan al-Qur'an. Ia merupakan tawkid (penekanan) ${ }^{11}$

d. Tafsir ayat 88 surah al-Isra'

\footnotetext{
${ }^{9}$ QS. Al-Isra'/17: 90-93.

${ }^{10}$ Muammad Syyaid Tantawi, At-Tafsir al-Wasith lilqur'an al-Karim (Kairo: Dar as-Sa'adah, 1982), juz-8, 425.

${ }^{11}$ Muhammad Yususf Abu Hayyan al-Andalusi, Al-Bahr al-Muhith ( Bairut: Dar AlFikr, 1992), juz 7, 111.
} 
Katakanlah kepada mereka dan tantanglah agar mereka mendatangkan sesuatu yang serupa dengan al-Qur'ân, dan mereka pasti tidak akan mempu mendatangkannya, "Seandainya manusia dan jin bergabung dan saling membantu untuk mendatangkan sesuatu yang serupa al-Qur'ân ini dalam komposisi dan maknanya, mereka tidak akan mampu melakukannya, meskipun mereka bekerjasama dan saling membantu satu sama lain."

Seandainya mereka (bangsa Arab yang dikenal dengan ilmu bayan-nya) saling bahu-membahu menunjukkan kehebatannya membuat karya semisal al-Qur'an dari segi Balaghah dan nazam-nya, sungguh mereka akan mendapatkan kegagalan membuat dan menandingi bahasa dan tulisan semisal al-Qur'an. Mereka tidak akan mampu menandingiya, karena al-Qur'an adalah sebagai kitab mukjizat.

Ayat 88 surah al-Isra' memberikan jaminan tegas atas kemurnian al-Qur'an, karena mereka tidak akan berhasil membuat tandingan karya ilmiah secara keseluruhan persis seperti al-Qur'an. Ayat 88 memberikan pernyataan, bahwa manusia, jin bahkan seluruh mahluk sekalipun tidak mampu membuat tulisa seperti isi keseluruhan isi al-Qur'an.

Ayat 88 memiliki makna amm, mencakup keseluruhan al-Qur'an. Artinya, semua teks al-Qur'an, mulai dari surah pertama, sampai surah terakhir tidak akan bisa ditiru dan tidak akan ada yang bisa menandingainya.

Setelah keseluruhan ayat al-Qur'an tidak dapat ditiru dan tidak bisa ditandingi, kemudia Allah memberikan keringanan untuk membuat sepuluh (10) surah saja. Sebagai dispensasi dari ke gagalan keseluruhan sebelumnya, maka datanglah ayat 13 surah Hud.

2. Surah Hud ayat 13, Allah berfirman:

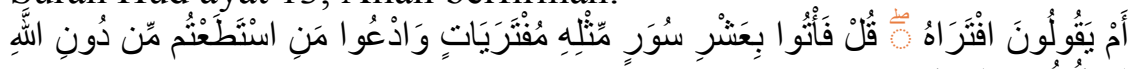

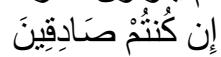
membuat-buat Al Quran itu", Katakanlah: "(Kalau demikian), maka datangkanlah sepuluh surat-surat yang dibuat-buat yang menyamainya, dan panggillah orang-orang yang kamu sanggup (memanggilnya) selain Allah, jika kamu memang orang-orang yang benar".

a.Sebab nuzul surah Hud ayat 13. 
Setelah penulis telusuri di kitab-kitab asbabun nuzul (seperti $a s b a b$ nuzul karya al-Wahidi dan lubab an-Nuqul karya Jalaluddin as-Suyuthi) dan kitab-kitab tafsir lainnya, ternyata ayat 13 surah Hud tidak memiliki sebab nuzul. Hanya saja setelah penulis kroscek melalui surah al-Qur'an secara keseluruhan, surah Hud masuk pada bagian surah makkiyah, seperti yang di jelaskan Ali as-Shobuni di dalam kitab Shafwah at-Tafasir, ${ }^{12}$

b.Munasabah surah Hud ayat 13 .

1) Munasabah ayat 13 dengan ayat sebelumnya.

Pada ayat 12 sebelunya dijelaskan, "Maka boleh jadi kamu hendak meninggalkan sebahagian dari apa yang diwahyukan kepadamu dan sempit karenanya dadamu, karena khawatir bahwa mereka akan mengatakan: "Mengapa tidak diturunkan kepadanya perbendaharaan (kekayaan) atau datang bersama-sama dengan dia seorang malaikat?" Sesungguhnya kamu hanyalah seorang pemberi peringatan dan Allah Pemelihara segala sesuatu.

Ayat sebelumnya tidak menjelaskan Mereka tidak bermaksud meninggalkan wahyu yang dibawa Rasulullah Saw. Hanya saja mereka tetap tidak mengakui al-Qur'an sebagai wahyu yang datang dari Allah. Mereka beranggapan ia merupakan buatan Nabi Muhammad Saw.

Imam Zamakhsyari berkata; mereka mengada-ada sebuah ayat disebabkan mereka bandal, tidak mau mengimbil petunjuk. Jika mereka ingin mengambil petunjuk dari apa yang dibawa Nabi Muhammada, tentu saja satu ayat sudah cukup bagi mereka. Tidak perlu meminta-minta diturunkan ayat lain. Apa lagi sampai mereka meminta agar diturunkan perbendaharaan dan bahkan minta didatangkkan malaikat. ${ }^{13}$

2) Munasabah ayat 13 dengan setelahnya

Pada ayat 13 surah Hud terdapat dua pesan. Pesan pertama

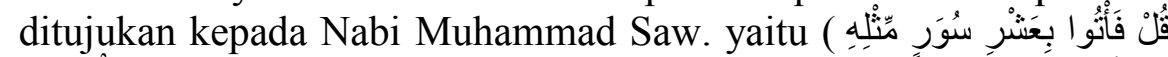

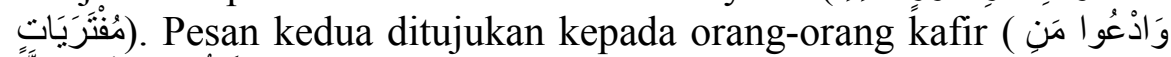

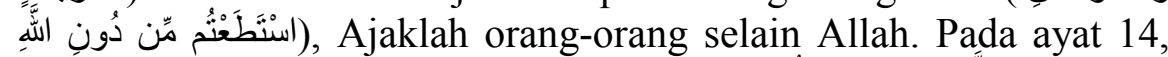

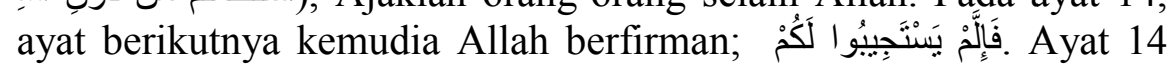
ini memiliki pengertian, apabila orang-orag kafir itu sudah tidak sanggup menerima tantangan karena ketidak mampuannya,

\footnotetext{
${ }^{12}$ Muhammad Ali as-Shabuni, Shafwah at-Tafasir (Kairo: Dar as-Shabuni, t. th), juz 02,5 .

${ }^{13}$ Jarullah Mahmud bin Umar az-Zamakhsyari, Al-Kasysyaf an Haqaiq al-Ta'wil wa Uyun al-Aqawil fi Wujuh al-Ta'wil (Bairut: Dar al-Fikr, 2006), juz 2, 261.
} 
ketahuilah bahwa al-Qur'an itu wahyu suci datang dari Allah. ${ }^{14}$ tidak boleh tidak mereka harus menyerah dan mengakui atas kebenaran wahyu yang dibawakan Rasulullah untuk mereka.

Lafaz jamak yang terdapat pada lafaz لكم pada ayat 14 adalah khitab kepada Nabi Muhammad dan orang-orang mukmin. Bisa saja lafaz lakum khitabnya hanya kepada Rasulullah seorang, sebagai pengagungan bagi beliau. Sedangkan pada lafaz pesanya ditujukan kepada orang-orang musyrik yang siap menerima tantangan, ${ }^{15}$ walaupun pada akhirnya mereka tidak akan bisa selamanya.

lam di dalam ayat itu memeberikan pemaknaan, yaitu waktu yang sudah lampau, artinya sebelum al-Quran diturunkan mereka juga tidak sipap memberikan jawaban. Sedangkan lafaz بستجييو menyimpan makna masa yang akan datang. Artinya setelah al-Quran selesai diwahyukan kepada Rasulullah sampai kapanpun mereka tidak akan bisa menjawabnya.

Jika kalian dan mereka yang membantu kalian tidak mampu membuat tandingan yang sebanding dengan al-Qur'ân, meskipun sekadar dibuat-buat, maka ketahuilah bahwa al-Qur'ân itu diturunkan dengan ilmu Allah, dan tak seorang pun yang mengetahui ilmu-Nya itu. Dan ketahui pula bahwa sesungguhnya tidak ada tuhan kecuali Allah. Tak satu pun, selain Allah, yang dapat melakukan pekerjaan-Nya. Dari itu, menyerahlah kalian setelah mendapati bukti yang memuaskan kalian ini, jika kalian memang benar-benar mau mencari kebenaran ${ }^{16}$

c. Analisis teks surah Hud ayat 13.

1) Makna Lafaz أم

Lafaz أم dalam ayat, menurut Imam Ibnu Qushairi adalah huruf istifham (untuk bertanya). Bermakna: apakah mereka menganggap cukup dengan apa yang telah diwahyukan kepadamu (Muhammad) tentang al-Qur'an? apakah mereka mengatakan, al-Qur'an bukan dari Allah? Kalau mereka mengatakan, al-Qur'an bukan dari Allah, katakan kepada mereka, buatlah seperti al-Qur'an.

2) Makna إفتر

\footnotetext{
${ }^{14}$ Fakhruddin al-Razi, Al-Tafsir al-Kabir aw Mafatih al-ghaib (Kairo: Maktabah Waqfiyah, t.th), juz 9, 163.

15 Jarullah Mahmud bin Umar al-Zamakhsyari, Al-Kasysyaf an Haqaiq at-Tanzil wa uyun al-Aqawil fi Wujuh at-Takwil (Bairut: Dar al_fikr, 206), Juz 2, 262

${ }^{16}$ Muhammad Qurash Shihab, Al-Qur'an dan Terjamah-Zekr, hal 89.
} 
Dhamir dalam lafaz iftarahu kembali kepada ayat sebelumnya (يوحى إليك). Artinya adalah; jika kalian menganggap wahyu yang diterima Rasulullah berupa buatan Rasulullah, maka katakan kepada mereka, datangkanlah sepeluh surah semisal wahyu itu juga dibuat oleh kalian. ${ }^{17}$

Seakan-akan dalam ayat dikatakan; bangkitlah, kami telah membuatnya padahal tidak diwahyukan kepada kami. Buatlah kalian kalam semisal al-Quran, dari diri kalian, tanpa minta bantuan orang lain. Kalian dikenal sebagai bangsa fashahah, seperi aku . Kalian memiliki kemampuan seperti yang aku miliki dalam berbicara.

3) Makna عشر سور (sepuluh surah)

Maksud 10 surah dalam ayat, adalah surah yang sudah ditentukan nama-namanya. Diriwayatkan dari Ibn Abbas; bahwa tuntutan sepuluh surah yang berada dalam ayat adalah surah-surah tertentu, yaitu, al-Baqarah, Ali Imran, an-Nisa', al-Ma'idah, alAn'am, al-A'raf, al-Anfal, al-Tawbah, Yunus dan Hud. ${ }^{18}$

4) Makna sis

Dalam surat Hud ayat 13 Allah mengatakan مثن. Bahasa ini memiliki arti "sama", dengan artian, bahwa sebuah karya yang berhasil diselesaikan, jika itu terjadi, maka harus memiliki kesamaan dengan al-Qur'an dalam keindahan struktur bahasanya, sama dalam keindahan bayannya dan keluasan dari maknanya. ${ }^{19}$

d. Tafsir ayat 13 surah Hud.

Bahkan apakah mereka mengatakan, Muhammad telah membuat-buatnya al-Qur'an itu, Katakanlah, "Kalau demikian, maka datangkanlah sepuluh surah-surah semisal dengannya, dalam masalah kefasihan bahasa dan ketinggian paramasastranya yang dibuat-buat, karena sesungguhnya kalian sama denganku adalah orang-orang Arab yang fasih dalam berbahasa. Allah swt. menantang mereka untuk pertama kalinya supaya mereka mendatangkan sepuluh surah, kemudian pada tantangan yang berikutnya cukup hanya dengan satu surah saja dan panggillah orang-orang yang kalian sanggup memanggilnya selain Allah, jika kalian memang orang-orang yang

\footnotetext{
${ }^{17}$ Fakhruddin al-Razi, Al-Tafsir al-Kabir aw Mafatih al-ghaib (Kairo: Maktabah Waqfiyah, t.th), juz 9, 162.

${ }^{18} \mathrm{Abu}$ Hayyan al-Andalusi, al-Bahr al-Muhit fi al-Tafsir (Bairut : Dar al-Fikr, 1992), juz VI, 130.

${ }^{19}$ Abu Hayyan al-Andalusi, al-Bahr al-Muhit fi al-Tafsir (Bairut : Dar al-Fikr, 1992), juz VI, 130.
} 
benar. di dalam tuduhan kalian yang menyatakan, bahwa al-Quran itu hanyalah buat-buatan belaka.

Fakhruddin mengatakan; para ulama berbeda-beda dalam menilai keagungan yang dimiliki al-Qur'an. Ada yang berkata dari segi fashahah, uslub (redaksi), tidak saling bertentangan ayatnya, mencakup banyak disiplin keilmuan, ilmu sharaf dan mencakup kabar-kabar ghaib. Hanya saja pendapat Fakhruddin sendiri dan pendapat mayoritas ulama mengatakan, bahwa nilai kehebatan ke i'jazan terbesar al-Quran adalah dari segi fashahah-nya. Jika sekiranya kehebatan al-Qur'an dinilai dari banyaknya ilmu-ilmu yang terdapat didalamnya, atau karena kabar ghaib atau karena tidak saling bertentangan, tentu Allah tidak akan mengetakan إفتراه, Allah menyebutkan lafaz iftarahu karena lafaz ini mengandung pesan fashohah. ${ }^{20}$

Kegagalan 10 surah yang mereka alami masih saja tidak menjadikan mereka pasrah dan menerima terhadap wahyu (alQur'an) sebagai kitab suci. Sifat dan karakter yang sudah mengakar tidak mudah menyerah begitu saja, mereka tetap saja menilai alQur'an sebagai akal-akalan Nabi Muhahammad Saw. sikap keras pada al-Qur'an dapat di gambarkan pada surah Yunus ayat 38 untuk membuat satu surah, karena sudah gagal dalam 10 surah. Membuat satu surah ini merupakan dispensasi dari keseluruhan al-Qur'an dan sepuluh surah, akhirnya menjadi satu surah.

3. Surah Yunus ayat/10: 38 Allah berfirman

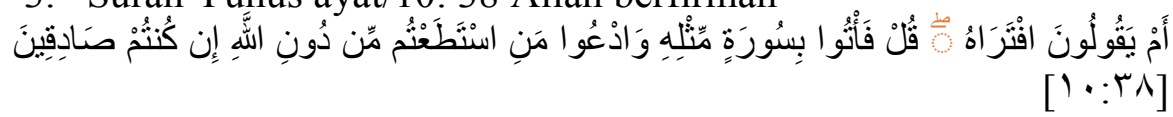

"dan jika kamu (tetap) dalam keraguan tentang Al Quran yang Kami wahyukan kepada hamba Kami (Muhammad), buatlah satu surat (saja) yang semisal Al Quran itu dan ajaklah penolongpenolongmu selain Allah, jika kamu orang-orang yang benar ". ${ }^{21}$

a. Sebab nuzul surah Yunus ayat 38

Setelah penulis telusuri di kitab-kitab asbabun nuzul dan kitabkitab tafsir, ternyata ayat 38 surah Yunus tidak memiliki sebab nuzul. Namun setelah penulis kroscek melalui surah secara umum, surah Yunus masuk pada bagian surah makkiyah. Pendapat ini

${ }^{20}$ Fakhruddin Muhammad bin Umar al-Razi, Al-Tafsir al-Kabir aw Mafatih alghaib (Kairo: Maktabah Waqfiyah, t.th), juz 9, 163.

${ }^{21}$ Depag RI, QS. Al-Baqarah/2: 23. 
dituliskan Muhammad Tahir bin Asyur dalam kitabnya At-Tahrir wa at-Tanwir. Beliau sependapat dengan jumhur ulama yang samasama mengatakan Hud bagian dari Makkiyah. ${ }^{22}$ Hanya saja sebagian ulama mengatakan, bahwa surah Yunus adalah bagian dari surah madaniyah, pendapat ini disampaikan Jalaluddin as-Suyuti dalm $\mathrm{Al}$ Itqan fi Ulum al-Qur'an.

Ayat 38 ini sengaja penulis letakkan di urutan ketiga dari klasifikasi penyusunan tematik, karena ia lebih khusus dari pada ayat 13 surah Hud. Penyusunan ini mengunakan metode makkimadani dan amm-khas karena ayat 38 sudah tidak memiliki sebab nuzul. Ayat 13 surah Hud lebih umum, sedangkan ayat 38 surah Yunus lebih khusus.

b. Munasabah ayat 38 surah Yunus dengan ayat 37sebelumnya

Pada ayat 37 sebelumnya dikatakan; dan tidak mungkin alQur'an ini dibuat-buat oleh selain Allah. Tetapi al-Qur'an membenarkan kitab-kitab yang sebelumnya dan menjelaskan hukum-hukum yang telah ditetapkannya, tidak ada keraguan di dalamnya , diturunkan dari tuhan seluruh alam. ${ }^{23}$

Ayat 37 memiliki makna nafi baligh, yaitu memberikan landasan, bahwa al-Qur'an betul-betul datang dari sisi Allah, yang isinya adalah membenarkan membenarkan kitab-kitab sebelumya

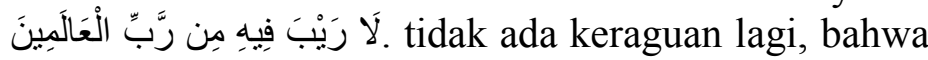
al-Qur'an datang dari tuhan semesta alam.

La raiba memilki makna istighraq, yaitu tidak perlu diragukan sedikpun. Lafaz itu membrika jawaban kepada orang-orang Qurasy yang telah meragukan otentisitas al-Qura'n sebagai kitab samawi. Denag beranggapan, al-Qur'an tidak lain hanya sebagai metos orangorang terdahulu.

Pada ayat 38, mereka berkata, أَمْ يَقُقُلُونَ افْتَرَاهُ : Muhammad sendiri yang membuatnya al-Qur'an, bukan dari sisi Allah. Padahal ayat 37 sebelumnya sudah menegaskan, bahwa al-Qur'an benar-benar dari sisi Allah. ${ }^{24}$

c. Munasabah ayat 38 surah Yunus dengan ayat setelahnya

\footnotetext{
${ }^{22}$ Muhammad Tahir bin Asur, At-Tahrir wa at-Tanwir (Tunis: Dar Suhnun, t.th), juz 11,77 .

${ }^{23}$ Imam Ghzali Masykur dkk, Almumayyizah al-Qur'an Tejwid berwarna, Translitrasi Perkata, Terjemah Perkata ( Bekasi: Cipta Bagus Segara, t.th), 213.

${ }^{24}$ Muhammad Syyid Thonthowi, Tafsir al-Wasith lil Qur'an al-Karim (Kairo: Dar as-Sa'adah, 1979), juz 7, 71-72
} 
Ayat 39 memberikan pernyataan; bahkan yang sebenarnya, mereka mendustakan apa yang mereka belum mengetahuinya dengan sempurna padahal belum datang kepada mereka penjelasannya. Demikianlah orang-orang yang sebelum mereka telah mendustakan (rasul). Maka perhatikanlah bagaimana akibat orang-orang yang zalim itu.

Mereka sudah memberika penilaian nigatif pada wahyu alQur'an, padahal mereka belum menalaah isinya. Sifat mereka (orang-orang musrik) pada masa Rasulullah sama saja dengan orang-orang kafir pada masa lalu, ketika menghadapi resul mereka. Kwahyu yang diterima oleh para rsul sudah dinilai palsu sebelum mereka mengetahui isinya terlebih dahulu. Begitu pula kepada alQur'an.

Sikap mereka itu tidak lain, karena ingin mempertahankan keyakinan yang sudah mengakar melalui nenek moyang mereka sebelumnya. padahal keyakinan nenek moyang tidak memiliki dasar, mereka hanya ikut-ikitan begitu saja, tanpa ada dalil. Selain itu mereka sudah merasa, bahwa risalah yang dibawa Nabi Muhammad tidak cocok dengan selera dan agama mereka. Seperti apapun kenbenarnya, bahkan sampai melebihi sinar matahari kesohehannya, sudah dari awal mereka tidak akan bakal menerima keberadaannya. ${ }^{25}$

d. Analisis teks ayat 38 surah Yunu

1) Lafadz سورة

Lafadz سورة adalah bentuk mufrad (singgle) yang hanya memiliki satu arti. سورة termasuk lafaz nakirah (umum) tidak tertuju pada surah tertentu.

Dalam ayat 38 surah Yunus, perintahnya tidak tertuju pada surah tertentu. Tetapi memiliki kebebasan memilih, mana saja surah yang hendak ditiru, mulai dari surah terpanjang sampai surah terpendek. ${ }^{26}$

2) Lafadz من

Lafadz مثلـ artinya; sama. Yaitu karya yang berhasil dituliskan memiliki kesamaan dalam segala dimensi dengan al-Qur'an. Tanpa mengurangi sedikitpun.

e. Tafsir ayat 38 surah Yunus

\footnotetext{
25 Ibud, 73.

${ }^{26}$ Muhammad Syyid Thonthowi, Tafsir al-Wasith lil Qur'an al-Karim (Kairo: Dar as-Sa'adah, 1979), juz 7, 72
} 
Akan tetapi, orang-orang musyrik itu berkata, "Muhammad telah membuat-buat al-Qur'ân dari dirinya sendiri!" Katakanlah kepada mereka, wahai Rasul, "Jika al-Qur'ân ini adalah hasil karya manusia, maka datangkanlah satu surat yang semisal dengannya. Mintalah pertolongan kepada orang-orang selain Allah yang kalian kehendaki, jika kalian memang benar menganggap al-Qur'ân adalah hasil karyaku." 27

Patutkah mereka mengatakan, "Muhammad membuat-buatnya." yakni Nabi Muhammad saw. telah membuatnya sendiri. Katakanlah, "Kalau benar yang kalian katakan itu, maka cobalah datangkan sebuah surah seumpamanya dalam hal kefasihan dan keparamasastraannya yang kalian buat sendiri, bukankah kalian itu adalah orang-orang Arab yang fasih dalam berbahasa sama denganku. Panggillah untuk membantu dalam hal ini siapa-siapa yang dapat kalian panggil selain Allah jika kalian orang-orang yang benar bahwasanya al-Quran itu adalah buatan belaka, niscaya kalian tidak akan mampu melakukannya. ${ }^{28}$

Setelah mereka gagal mendatangkan satu surah, maka datanglah tantangan berikutnya, yaitu surah al-Baqarah ayat 23, menegaskan, jika kalian tidak mampu kecuali bersekongkol dengan orang banyak, maka ajaklah semua tuhan-tuhan kalian, ajaklah pembesar-pembesar kalian, jika kalian mengaku benar.

4. Surah Al-Baqarah ayat 23, Allah berfirman;

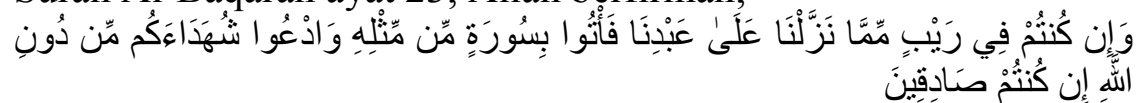

"Dan jika kamu (tetap) dalam keraguan tentang Al Quran yang Kami wahyukan kepada hamba Kami (Muhammad), buatlah satu surat (saja) yang semisal Al Quran itu dan ajaklah penolongpenolongmu selain Allah, jika kamu orang-orang yang benar"

a. Sebab nuzul al-Baqarah ayat 23.

Ayat 23 surah al-Baqarah adalah ayat yang tidak memiliki sebab nuzul, ia turun begitu saja tanpa ada permasalahan sebelumnya. Ketika dikroscek melalui keterangan surah, surah al-Baqarah ternyata masuk pada bagian dari surah madaniyah. Pendapat ini terdapat dalam kitab Al-Jami' Liahkam al-Qur'an, yang di kenal dengan Tafsir al-Qurthubi ${ }^{29}$

\footnotetext{
${ }^{27}$ Muhammad Quraish Shihab et al, Zekr, hal 85.

${ }^{28}$ Jaluddin Abdurrahman as-Suyuthi, Tafsir Jalalain (Surabaya: al-Hidayah, t.th)

29 Muhammad bin Ahmad al-Anshari, Al-Jami' Liahkam al-Qur'an (Kairo: Maktabah al-Iman, 2006), Juz 1, 122.
} 
Abu Hayyan al-Andalusi mengatakan; ayat 23 surah al-Baqarah turun untuk semua orang kafir. Ibn Abbas dan Muqatil berkata; ayat 23 al-Baqarah turun mengenai permasalahan orang-orang Yahudi. Namun Abu Hayyan menegaskan, bahwa ayat 23 itu lebih tepat turun untuk semua orang kafir, karena pada ayat sebelumnya Allah menegaskan tentang keesaan-Nya dan ke kuasaanya dalam menciptakan alam semesta ini. ${ }^{30}$

b. Munasabah ayat 23 surah al-Baqarah dengan ayat 22 sebelumnya.

1) Munasabah ayat 23 dengan ayat 22 al-Baqarah sebelumnya.

Dalam ayat 22 isinya adalah membicarakan tentang kekuasaan Allah, menciptakan bumi dan langin, lalu turunlah air kebumi, maka tumbuhlah berbagai macam buah-buahan

Proses penciptaan dari sebelumnya tidak ada bentuk materi apapun (kosong), Allah mampu mengadakan kekosongan menjadi benda nampak yang dapat dilihat dan dapat dirasakan oleh panca indra.

Begitu hebatnya kekuasaan Allah yang tergambar pada ayat 22, maka tidak heran ketikan dalam ayat 23 Allah memberikan tantangan kepada manusia untuk mendatangkan teks semisal alQuran apabila sama-sama memiliki kekuasan dan kemampuan seperti Allah. Keraguan mereka terhadap al-Qura'an mendapatkan tantangan dari Allah.

Tantangan itu memberikan jaminan, bahwa manusia tidak akan bisa mendatangkan teks semisal al-Qur'an. Ia juga memberikan pernyataan bahwa al-Qur'an akan selalu terjaga kemurnian dan kesuciannya.

2) Munasabah ayat 23 al-Baqarah dengan 24 sesudahnya

Pada ayat 24 Allah berfirman

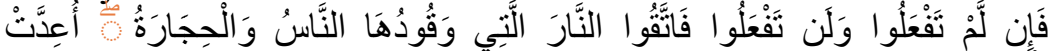

$$
\begin{aligned}
& \text { لِلَْافِرِينَ }
\end{aligned}
$$

\footnotetext{
${ }^{30}$ Abu Hayyan al-Andalusi, al-Bahr al-Muhit fi al-Tafsir (Bairut : Dar al-Fikr, 1992), juz-1, 166
} 
Di dalam kaidah bahasa arab (nahwu), apabila fi'il mudhari'

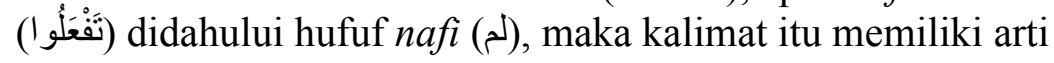
madhi (zaman lampau).

Artinya adalah; walaupun al-Quran belum diturunkan sekalipun ke muka bumi (kepada Nabi Muhammad Saw.), manusia pasti tidak akan mampu mendatangkan teks bahasa seperti tingginya bahasa al-Qur'an.

Ketika fi 'il mudhari' (تَفَعَُوا), yang memiliki arti masa depan, didahuli huruf nafi sekaligus istiqbal (لَ), yang juga memilki arti peniadaan dan masa depan, maka kalimat itu memiliki pengertian; masa depan yang tidak akan terjadi.

Artinya adalah; sampai kapanpun, bahkan menjelang akhir zaman, manusia tidak akan mampu mendatangkan teks bahasa seperti tingginya bahasa al-Qur'an.

Ketika gagal dengan tantangn itu, maka hati-hatilah wahai manusia, mengingkari teks suci (al-Qur'an) ancamannya adalah neraka.

C. Analisis teks ayat 23 surah al-Baqarah

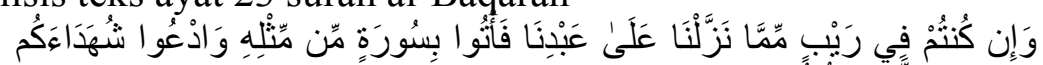

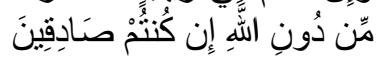

1) ريب Arti lafadz

Lafadz ريب artinya adalah ragu. Mereka tetap berada dalam كنتم keraguan pada nilai otentisitas kewahyuan al-Qur'an. Lafadz memberikan makna masa lampau, karena kuntum merupakan fi'il madhi yang maknanya menunjukan pada perbuatan yang sudah terjadi dimasa lampau. Artinya, sejak awal al-Qur'an turun sampai dengan saat ini, mareka masih saja memiliki keraguan pada alQur'an.

teks ini memiliki makna umum. Muhammad bin Ahmad al-Anshari yang dikenal dengan Imam Qurthubi, mengatakan dalam karyanya Al-Jami' al-Ahkam al-Qur'an Tafsir alQur'thubi, taks lafadz itu memiliki makna umum, pesannya bisa tertuju kepada orang mukmin untuk lebih meyakinkan keimanannya, juga pula tertuju kepada orang kafir pada saat awal al-Qur'an diturunkan dan bahkan sampai sekarang.

2) Lafadz سورة

\footnotetext{
${ }^{31}$ Muhammad bin Ahmad al-Anshari, dikenal dengan Imam Qurthubi, Al-Jami' alAhkam al-Qur'an Tafsir al-Qur'thubi (Kairo: Maktabah al-Iman, 2006), juz 1, 178.
} 
Maksud surah dalam ayat itu dapat diartikan, surah apa saja, karena ia lafadznya nakirah. Fakhruddin al-Razi mengatakan dalam karyanya Mafatih al-Ghaib, surah yang dimaksudkan bisa juga surah al-Kawsar, al-Ashr dan al-Kafirun. Itu merupakan surah pendek yang lebih memungkinkan untuk dapat ditiru. ${ }^{32}$

3) Lafadz من منا

Dhamir yang terdapat pada lafadz itu memiliki perbedaan pemahaman diantara ulama. Qur'an)

Ada yang memahami, dhamir itu kembali kepada ma (al-

Ada yang berpendapat dhamir itu krmbali kepada "abdina" (Nabi Muhammad)

Ulama nahwu berbeda dalam menetukan makna من. Ada yang berpendapat, min tidak lain hanya sebagai zaidah (tambahan kata). Ada pula yang berpendapat min sebagai bayan liljinsi (menerangkan jenis-nejis disiplin keilmuan), ini merupakan pendapat ulama Kufah dan Bashrah. Pendapat ini dipertegas oleh Jalaluddin as-Suyuthi dalam Tafsir Jalalin, bahwa min memiliki makana lilbayan. ${ }^{33}$

Ketika من memiliki bayan liljins, maka akan memiliki banyak penafsiran ketika dikembalikan kepada wahyu yang diturunkan Allah

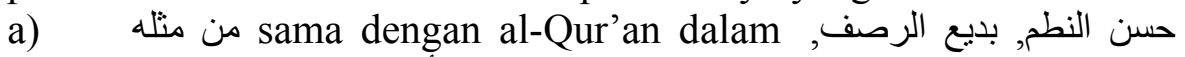
عجيب السرد, غرابة الأسلوب و الإيجاز, و إتقان معانيه

b) Sama dengan al-Qur'an dalam memberika kabar ghaib. Sesudah terjadi pada masa lampau dan yang akan terjadi di masa depan

\footnotetext{
${ }^{32}$ Fakhruddin al-Razi, Mafatih al-Ghain atauTafsir al-Kabi (Kairo: Maktabah alWaqfiyah, 2003), juz 1, 118

33 Jalaluddin al-Mahalli dan Jalaluddin as-Suyuthi, Tafsir al-Qur'an al-Adzi (Surabaya: al-Hidayah, t.th), juz-1, 4. Tafsir itu biasa dikenal dengan Tafsir Jalalain, karena pengarangnya dua Jalal (guru dan murid), walaupun belum dapat dipastikan batasan surah mana Jalaluddin al-Mahalli mengakhiri tulisan tafsirnya. Dari mana Jalaluddin as-Suyuthi melanjutkan karya gurunya. Dalam hal ini masih simpang siur dikalangan ulama' ada yang berpendapat : Jalaluddin al-Mahalli hanya menyelesaikan surah al-Fatihah, ada pula yang berpendapat; menyelesaikan juz pertama, yaitu sampai surah al-Isra'. Jalaluddin sebagai muridnya kemudia melanjutkan karya gurunya yang sudah meninggal sampai selesai sempurna.

Kesimpang siuran yang terjadi dikalangan ulama, dimana batasan mereka berdua (guru dan murid) berhenti dan memulai, karena dari awal surah sampai akhir surah metode penafsirannya sama, tidak dapat dibedakan antar keduanya. Seakan-akan tafsir jalalain itu dituliskan satu orang. Kejelian As-Suyuthi dalam mengikuti langkah gurunya dalam penafsiran al-Qur'an sampai-sampai hasilnya tidak dapat dibedakan, yang mana hasil karya beliau, yang mana hasil karya gurunya.
} 
c) Sama dengan al-Qur'an dalam segala cakupannya. Meliputi, amar, nahi wa'ad, wa'id, qashash, hikam dan mawa'idh.

d) Sama dengan al-Qur'an dalam kebenarannya, ketepatanya, kejujuranya, jaminannya dari perubahan dan jaminannya dari khurufat.Sama dengan al-Qur'an dalam segi bahasa arabnya

e) Senang ketika didengar, nilai kehebatannya tidak kunjung selesai, menjadi kitab yang terus-menerus dikaji, tidak pernah hilang sifat halawahnya dan disukai semua kalangan.

f) Sama dengan al-Qur'an dalam keberlanjutan teksnya dan nilai kemukjizatannya.Sama dengan al-Qur'an dalam keberadaannya seperti kitab-kitab wahyu sebelumnya, memberikan penyaksian, mereka sama-sama mengaku bahwa ia bukan dari Allah

g) memiliki pengertian; dari sosok yang tidak dapat menulis dan tidak bisa membaca

h) من منظك dari sosok yang tidak pernah belajar kepada ulama, tidak pernah hadir ke majlis hukama, tidak pernah dipengaruhi para pendeta, tidak pernah kelur kota, dinilai sebagai orang gila dan penyair dan penyihir.

i) Nabi Muhammad Saw. Sama-sama dari jenis manusia, yang memiliki sifat layaknya manusia. ${ }^{34}$

4) Lafadz شُهَدَاءَكَمُ memiliki dua makna

a) Benda-benda yang dijadikan sebagai tuhan sesembahan oleh mereka. Yaitu patung-patung yang disembah, dianggap sebagai tuhan. Diyaqini dapat memberikan manfaat dan mudharat.

b) Pembesar-pembesar dan orang-orang yang memiliki sifat yang sama dalam mengingkari apa-apa yang datang dari Nabi Muhammad. ${ }^{35}$

d. Tafsir ayat 23 surah al-Baqarah

Sekiranya kamu merasa ragu atau bimbang tentang apa yang Kami wahyukan kepada Muhammad, bahwa itu benar-benar dari Allah, maka buatlah sebuah surah yang sebanding dengan surah yang diwahyukan itu.

'Min mitslihi', min maksudnya di sini ialah untuk menjadi keterangan atau penjelasan, artinya ialah yang sebanding dengannya, baik dalam kedalaman makna maupun dalam keindahan susunan kata serta pemberitaan tentang hal-hal gaib dan sebagainya.

\footnotetext{
${ }^{34}$ Abu Hayyan al-Andalusi, al-Bahr al-Muhit fi al-Tafsir (Bairut : Dar al-Fikr, 1992), juz-1, 170-171.

${ }^{35}$ Fakhruddin Muhammad bin Umar ar-Razi, Al-Tafsir al-Kabir aw Mafatih alGhaib (Kairo: Al-Maktabah al-Waqfiyah, 2003), juz -2, 119.
} 
'surah' ialah suatu penggal perkataan yang mempunyai permulaan kesudahan dan sekurang-kurangnya terdiri dari tiga ayat.

Ajaklah tuhan-tuhanmu yang kamu sembah itu (selain dari Allah) untuk menjadi penolong-penolongmu, jika kamu orang-orang yang benar, bahwa al-Qur'an itu hanyalah buatan dan ucapan Muhammad belaka, maka cobalah lakukan demikian, bukankah kamu orang-orang yang berlidah fasih seperti Muhammad pula?

Kedahsatan dan keagungan al-Qur'an dapat dilihat dari kandungan surat al-Baqarah 23 yang menggambarkan, siapa saja yang meragukan otentisitas al-Qur'an, maka mereka ditantang oleh al-Qur'an untuk membuatkan satu surat saja, sebagai tandingannya, bahwa mereka mampu menyamai dan mengarangnya. Walaupun mereka mengajak orang lain. Mereka dipastikan tidak akan mampu membuatnya.

Ayat ini merupakan tantangan bagi mereka yang meragukan kebenaran al-Qur'an, penyusunan bahasa seperti itu tidak dapat ditiru walaupun dengan mengerahkan semua ahli sastera dan bahasa sekalipun, karena ia merupakan mukjizat Nabi Muhammad s.a.w.

Al-Suddi dari Abu Malik mengatakan: maksud dari shuhada' adalah teman-teman kalian, kaum-kaum lain yang siap membantu mengarang dan menyusun, para tuhan (barhala-barhala) yang dapat menolong dalam pembuatan karya. Mereka tidak akan berhasil membuatnya.

Mujahid mengatakan: wa ud 'u shuhada' akum, adalah orangorang yang pakar dalam Ilmu Fashahah.

Mujahid, Qatadah, Ibnu Jarir, Zamakhshari dan Fakhruddin al-Razi memiliki pendapat yang sama dengan Umar, Ibn Mas'ud, Ibnu 'Abbas dan Sayyidina Hasan: ayat 23 memiliki makna am, ditujukan kepada semua orang, terlebih orang-orang kafir Makkah. Baik indipidu atau kolektif, bisa baca-tulis atau tidak.

Ditujkan kepada kafir Makkah, karena Orang Makkah dinilai lebih fasih dari bangsa lain dalam segi bahasa.

Tantangan al-Baqarah 23, dijawab oleh ayat setelahnya [alBaqarah 24] فإن لم تفعلوا ولن تفعلوا , bahwa orang-orang tidak akan bisa menandingi dan membuat karya seperti al-Qur'an.

Dalam kaidah bahsa Arab, lan memiliki makna linafyi alta'bid fi al-mustaqbal (meniadakan kesempatan selamanya untuk 
masa depan). Ini adalah informasi pasti dan nyata, bahwa la-Qur'an akan terjamin kemunirniannya sampai akhir masa. ${ }^{36}$.

\section{A. Penafsiran ayat}

Ayat 88 surah al-Isra', ayat 13 surah Hud, ayat 38 surah Yunus dan ayat 23 surah al-Baqarah, walaupun ada perbedaan pendapat ulama terkai am dan khas-nya khitab ayat, namun ketikan dimasukan kepada kaidah Ushul fiq, semua teks tetap berlaku atas keumumannya.

Artinya adalah; kasus yang terjadi yang menyebabkan ayat turun, tidak dapat mengekang dan tidak dapat membatasi pada nilai keumuman ayat.

Walaupun ayat turun pada masa lampau, bukan berarti orangorang pada saat ini tidak mendapatkan tantangan dengan pesan ayat. Siapapun yang memiliki sifat dan karakter yang sama dalam penulakannya kepada al-Qur'an dan kebenciannya kepada nabi Muhammad sebagai pembawa risalah, maka ia juga dapat masuk pada pesan ayat.

Walaupun ayat diturunkan di Arab, bukan berarti orang ajami tidak mendapatkan tantangn pesan ayat. Dimanapun tempat berada kapanpun waktunya, ayat ini tetap hidup pesannya. Al-Qur'an akan selalu dapat menjawabnya. ${ }^{37}$

Jika dicermati dengan baik, ayat-ayat diatas akan memberikan pemaknaan yang luar biasan. Setelah Nabi Muhammad diangkat menjadi Rasul, dibekali kitab al-Qur'an sebagai dasar dan bukti terhadap ke Rasulannya, mereka mengingkari, tidak mahu kepada kitab (al-Qur'an) yang telah diwahyukan kepada Nabi Muhammad. Berkata, bahwa al-Qur'an adalah sebagai "sihrani" (al-Qur'an dan taurat keduanya sihir). Sikap seperti itu muncul ketika al-Qur'an belum sepenuhnya lengkap 114 surah, karena kejadian ini Rasulullah masih berada di Makkah, kemudian turun surat al-Qashas ayat 49, sebagai jawaban terhadap tindakan itu.

Katakanlah: "Sesungguhnya jika manusia dan jin berkumpul untuk membuat yang serupa Al Quran ini, niscaya mereka tidak akan dapat membuat yang serupa dengan dia, sekalipun sebagian mereka menjadi pembantu bagi sebagian yang lain".

\footnotetext{
${ }^{36}$ Imaduddin Ismail bin Kathir, Tafsir al-Qur'an al- 'Azim (Jiddah : Kandah, t.th), juz I, 68. Kitab ini lebih dikenal dengan nama Tafsir ibn Katsir.

${ }^{37}$ Muhammad Abdul Adim al-Zurqani, manahil al-Irfan fi Ulum al-Qur'an (Kairo: Dar as-Salam, 2006), juz 1, 104.
} 
Setelah mereka gagal membut seluruh al-Qur'an, maka datanglah tantangan baru ayat 13 surah Hud yang lebih ringan dari sebelumnya, yaitu 10 surat.

Menurut keterangan yang diambil dari kitab al-Bahr al-Muhit fi al-Tafsir: bahwa, 10 surah itu ditujukan kepada surat tertentu. Diriwayatkan melalui sanad Ibnu 'Abbas r.a. berkata: sesungguhnya surat yang dijadikan bahan tantangan adalah surat. Al-Baqarah, Ali 'Imran, al-Nisa', al-Ma'idah, al-An'am, al-A'raf, al-Anfal, al-Taubah, Yunus dan Hud. ${ }^{38}$

Kegagalan selalu menyertai mereka. Sudah dua kail mengalami kegagalan, sekarang masuk pada tahapan ketiga, yaitu membuat satu surat.

Sayyid Thantawi mengatakan: dalam redaksi ayat 38 surat Yunus, terdapat lafaz\} "Suratin" menunjukkan pada isim nakirah. Bahasa ini memberikan pengertian, mereka tidak dituntut dengan surat tertentu. Akan tetapi Allah memberikan kebebasan penuh memilih surat mana saja dalam al-Qur'an yang disukai, hingga surat terkecil.

Setelah suratin, diiringan lafaz mithlihi, bersama dengan damir yang merujuk kepada al-Qur'an. Dalam bahasa ini memiliki makna, tuntutannya adalah membuat karya yang serupa dengan alQur'an dari segi kesempurnaan dan keindahan nazam, uslub, makna dan pengaruhnya. ${ }^{39}$

Kebebasan memilih surah itu tidak membuat mereka berhasil dalam menandingi al-Qur'an. Kegagalan ketiga ini membuat mereka semakin tidak berdaya, bahkan selama bertahun-tahun al-Qur'an turun di Makkah mereka tetap saja tidak menunjukkan keberhasilannya. Pada ahirnya Rasulullah hijrah ke Madinah dan turunlah surah alBaqarah ayat 23 , yang isinya sama, menantang membuat satu surah. Lalu dipertegas oleh ayat 24 al-Baqarah. Mereka tidak akan mampu: . فإن لم تفعلوا ولن تفعلو . Mereka tidak melakukan dan tidak akan pernah melakukan.

Kegagalan total selama puluhan tahun membuat bahasa dan sastra yang menjadi kebanggaan mereka lenyap begitu saja. Yang tersisa hanya "shi "ir jahili". menandakan alangkah bagusnya tutur bahasa mereka pada saat itu, maka tidak heran jika al-Qur'an diturunkan sebagai tandingannya.

\footnotetext{
${ }^{38}$ Muhammad Yusuf Abu H\{ayyan al-Andalusi, al-Bahr al-Muh\}it\} fi al-Tafsir (Bairut: Dar al-Fikr, 1992), juz VI, 131.

${ }^{39}$ Muhammad Sayyid T $\{$ ant\}wi, al-Tafsir al-Wasit\} li al-Qur'an al-Karim (Kairo: Dar al-Sa'adah, t,th), Mujallad VII, 72.
} 


\section{Epilog}

Setelah dijelaskan panjang lebar, maka penulis akan memberikan kongklusi singkat pada penafsiran ayat diatas. Abu Hayyan al-Andalusi mengutip pendapat Abu Abd Allah al-Razi: macam-macam tantangan yang diberikan al-Qur'an ada empat tingkatan. Ini juga dikatakan sebagai tinggkatan mukjizad al-Qur'an. Itu pula merupakan jaminan atas kemurnia al-Qur'an

1. Jaminan kemurnian al-Qur'an secara keseluruhan. Dinyatakan dalam ayat 88 surah al-Isra'. Mereka gagal dalam mendatangkan karya menadingi keseluruhan al-Qur'an.

2. Jaminan kemurnian al-Qur'an membuat 10 surah. Dinyatakan dalam surah Hud ayat 13. Gagal lagi untuk meniru dan menyamakan dengan al-Qur'an

3. Jamianan kemurnian membuatkan 1 surah. Mereka gagal dalam mendatangkan dan meniru teks semisal al-Qur'an. Pernyataan ini terdapat dalam ayat 38 surah Yunus. Tantangannya hanya membuatkan satu surah saja, itu-pun bebas, mau memilih surah mana saja. Dari surah terpanjang, sampai surah terpendek. Tidak ada ketentuan.

4. Jaminan terahir atas kemurnian al-Qur'an tercatat dalam ayat 23 surah al-Baqarah. Sekalipun mereka gotong royong mengajak semua manusia, laki-perempuan, kafir atau mukmin, yang memiliki keraguan pada al-Qur'an, mereka dapat dipastikan tidak akan bisa mendatangkan dan meniru alQur'an.

\section{Daftar Pustaka}

Al-Qur'an

Andalusi (al), Muhammad Yususf Abu Hayyan, Al-Bahr al-Muhith ( Bairut: Dar Al-Fikr, 1992)

Asur, Muhammad Tahir bin, At-Tahrir wa at-Tanwir (Tunis: Dar

Suhnun, t.th)

Daud, Muhammad Muhammad, Kamal Lughah al-Qur'an Bain Haqaiq al-I'ja wa Awham al-Khushum ( Kairo: Dar al-Mannar, 2007) 
Kathir, Imaduddin Ismail bin, Tafsir al-Qur'an al-'Azim (Jiddah : Kandah, t.th), juz I, 68. Kitab ini lebih dikenal dengan nama Tafsir ibn Katsir.

Mahalli (al), Jalaluddin dan Jalaluddin as-Suyuthi, Tafsir al-Qur'an al-Adzi (Surabaya: al-Hidayah, t.th)

Masykur, Imam Ghzali dkk, Almumayyizah al-Qur'an Tejwid berwarna, Translitrasi Perkata, Terjemah Perkata ( Bekasi: Cipta Bagus Segara, t.th)

Qurthubi (al), Muhammad bin Ahmad al-Anshari, dikenal dengan Imam Qurthubi, Al-Jami' al-Ahkam al-Qur'an Tafsir alQur'thubi (Kairo: Maktabah al-Iman, 2006),

RI, Depertemen Agama, Al-Qur'an dan terjamah (Bandung, AlJumanatul Ali, 2005)

Razi (al), Fakhruddin Muhammad bin Umar, Al-Tafsir al-Kabir aw Mafatih al-ghaib (Kairo: Maktabah Waqfiyah, t.th)

Shabuni (al), Muhammad Ali, Shafwah at-Tafasir (Kairo: Dar asShabuni, t. th)

Shihab, Muhammad Qurash, Al-Qur'an dan Terjamah-Zekr

Suyuthi (al), Jalaluddin Abdurrahman, Lubab an-Nuqul fi Asbab alNuzul (Kairo: Dar Al-Haitsam, 2005)

Suyuthi (al), Jaluddin Abdurrahman, Tafsir Jalalain (Surabaya: alHidayah, t.th)

Tantawi, Muammad Syyaid, At-Tafsir al-Wasith lilqur'an al-Karim (Kairo: Dar as-Sa'adah, 1982)

Zamakhshari (al), Abi al-Qasim Jar Allah Muhammad bin 'Uar, alKashshaf 'An Haqaiq al-Tanzil wa 'Uyun al-Aqawil fi Wujuh al-Ta'wil (Bairut: Dar al-Fikr,2006),

Zurqani (al), Muhammad Abdul Adim, manahil al-Irfan fi Ulum alQur'an (Kairo: Dar as-Salam, 2006) 